\title{
Aktivitas Antibakteri Ekstrak Etanol Daun Cayratia trifolia L. Domin. Terhadap Bakteri Escherichia coli
}

\author{
${ }^{1}$ Muhammad Ilyas Y, ${ }^{2}$ Sri Susanti, ${ }^{3}$ Karmilah, ${ }^{3}$ Indriyani Pratiwi Hapsari \\ ${ }^{1}$ Prodi DIII Analis Kesehatan, Politeknik Bina Husada Kendari Jl. Sorumba No.17 Kendari \\ ${ }^{2}$ Prodi Ilmu Keperawatan, Fakultas Kedokteran Universitas Halu Oleo Kendari \\ ${ }^{3}$ Prodi DIII Farmasi, Politeknik Bina Husada Kendari \\ Email: ilyasyusufmuhammad.apt@gmail.com
}

\begin{abstract}
Plant Cayratia trifolia L. Domin is one of the plants that can be used as a traditional medicine. One of them is the treatment of infectious diseases. Infectious diseases are the most disease suffered by the population in developing countries, including Indonesia. Some infectious diseases that can be caused by the bacterium Escherichia coli is a urinary tract infection or urinary tractus infection, diarrhea, prevalence of diarrheal diseases in Southeast Sulawesi Province was 7,3\% higher than the national prevalence of diarrhea is 3,5\% this study aims to determine the antibacterial activity of ethanol extract of leaves $C$. trifolia $L$. Domin against the bacteria E. coli. This type of research is experimental research design using cylinder cup consisting of 5 treatments. Each treatment consists of three repetitions. $C$. trifolia L. Domin leaves then C. trifolia L. Domin as test materials made concentration of $10 \%, 20 \%$ and $30 \%$. The results showed that ethanol extracts of leaves C. trifolia L. Domin with a concentration of $10 \%$ has an average value of $7,67 \mathrm{~mm}$ zone of inhibition concentration of $20 \%$ has an average value of $10,33 \mathrm{~mm}$ zone of inhibition and concentration of $30 \%$ has an average value 14,00 mm zone of inhibition. Results of ANOVA showed ethanol extract of leaves $C$. trifolia L. Domin had a zone of inhibition against Escherichia coli with different concentrations. And on the LSD (Least Significant Difference) concentration that was $30 \%$ effective in inhibiting the growth of bacteria E. coli.
\end{abstract}

Keywords: zone inhibition, leaves Cayratia trifolia L. Domin, Escherichia coli, Cylinder cup.

\section{Pendahuluan}

Penyakit infeksi merupakan penyakit yang paling banyak diderita oleh penduduk di negara berkembang, termasuk Indonesia (Kemenkes, 2014). Penyakit infeksi adalah multiplikasi bakteri yang merupakan bagian flora normal dari saluran gastrointestinal, kulit, dan lain-lain (Jawetz dan Adelberg., 2001).

Salah satu penyakit infeksi adalah penyakit diare, yang masih merupakan masalah kesehatan masyarakat di negara berkembang seperti di Indonesia, karena morbiditas dan mortalitas yang masih tinggi (Widoyono, 2005). Diare adalah penyakit dimana seorang penderita mengalami buang air besar yang sering dan memiliki kandungan air yang berlebihan. Diare kebanyakan disebabkan oleh infeksi bakteria, seperti bakteri E. coli, Shigella sp, Vibrio cholera, dan lain-lain. Diare dapat menyebabkan dehidrasi yang parah dan 
dapat mengancam jiwa bila tanpa ditindak lanjuti dengan pengobatan dan perawatan (Raina, 2011).

Beberapa penyakit infeksi yang dapat disebabkan oleh bakteri Escherichia coli adalah Infeksi Saluran Kemih (ISK) atau Urinarius Tractus Infection (UTI) adalah suatu keadaan adanya infasi mikroorganisme pada saluran kemih, Infeksi Saluran Kemih (ISK) adalah suatu keadaan adanya infeksi bakteri pada saluran kemih (Enggram, 1998).

Berdasarkan data Riset Kesehatan Dasar (RISKESDAS) tahun 2013 prevalensi penyakit diare di Provinsi Sulawesi Tenggara adalah 7,3 \% lebih tinggi dari prevalensi diare secara nasional yaitu 3,5\% (Kemenkes, 2014). Sedangkan prevalensi penyakit diare di Kota Kendari tahun 2013 adalah 1.664 per 100.000 penduduk (Dinas Kesehatan Kota Kendari, 2013).

Salah satu upaya pencegahan penyakit infeksi telah dilakukan terutama dengan penggunaan disinfektan dan berbagai macam antibiotik Golongan fluorokuinolon merupakan antibiotik yang efektif untuk infeksi saluran kemih dan untuk diare bakteri yang disebabkan oleh Shigella, Salmonella, E. coli toksigenik atau Campylobacter (Katzung, 2004). Salah satu golongan fluorokuinolon adalah siprofloksasin yang aktif terhadap bakteri gram positif dan bakteri gram negatif. Siprofloksasin terutama aktif terhadap bakteri gram negatif dan hanya memiliki aktivitas yang sedang terhadap bakteri gram positif (BPOM, 2008).

Penggunaan antibiotik perlu dipertimbangkan karena adanya angka kejadian resistensi yang semakin meningkat. Pada pasien infeksi saluran kemih yang menjalani rawat inap di salah satu RSUD di Yogyakarta, siprofloksasin merupakan antibiotik alternatif yang direkomendasikan apabila kombinasi SXTTMP (sulfametoksazol-trimetoprim) tidak dapat digunakan karena alasan resistensi. Resistensi E. coli terhadap siprofloksasin dilaporkan kurang dari 3\%. Beberapa ahli mendukung penggunaan siprofloksasin sebagai alternatif, dan dalam beberapa kasus sebagai lini pertama, untuk pengobatan ISK (infeksi saluran kemih) tanpa komplikasi. Meskipun efikasi turunan kuinolon sama dengan SXT-TMP, IDSA (Infectious Disease Society Of Amerika) tidak merekomendasikan turunan kuinolon sebagai lini pertama karena alasan resistensi dan juga untuk menjaga efektivitasnya pada pengobatan ISK dengan komplikasi, (Widoyono, 2005; Saepudin, 2006). 
Alternatif lain yang bisa digunakan untuk mengatasi penyakit infeksi adalah bahan dari alam atau obat tradisional dimana Indonesia merupakan negara yang memiliki ribuan jenis tumbuhan yang harus dilestarikan dan dimanfaatkan dengan baik. Sebagian besar tumbuhan tersebut dapat digunakan sebagai obat tradisional. Hal ini menandakan adanya kesadaran masyarakat untuk kembali ke alam dalam rangka mencapai kesehatan yang optimal dan untuk mengatasi berbagai penyakit secara alami (Wijayakusuma, 1997). Obat tradisional yang berasal dari tumbuhan dan bahan - bahan alami murni, memiliki efek samping, tingkat bahaya dan resiko yang jauh lebih rendah dibandingkan dengan obat kimia (Muhlisah, 2005).

Salah satu tanaman obat yang dapat digunakan sebagai obat tradisional adalah daun C. trifolia L. Domin. Daun Cayratia trifolia L. Domin digunakan untuk kebutuhan pengobatan, terutama untuk pengobatan alternatif (Utami, 2014). Hal ini dikarenakan tanaman $C$. trifolia $\mathrm{L}$. Domin mengandung senyawa metabolit sekunder yang diduga mempunyai efek antibakteri.

Kandungan kimia dari tumbuhan $C$. trifolia L. Domin antara lain kaempferol, myricetin, quercetin, triterpenes, epifriedelanol, yellow waxy oil, steroid, terpenoids, flavonoids, tannins, viniferin, ampelopsin. hydrocyanic acid, delphinidin, dan cyaniding (Kumar dkk., 2012). Kandungan flavonoid mampu menghambat dan membunuh mikroorganisme yang menyebabkan penyakit pada manusia (Grubben, 2004).

Berdasarkan hal tersebut di atas dan data empiris dari masyarakat, maka perlu dilakukan penelitian lebih lanjut untuk menguji apakah daun C. trifolia L. Domin. efektif sebagai antibakteri terhadap bakteri E. coli.

\section{METODE PENELITIAN}

Penelitian ini telah dilaksanakan pada bulan Mei-Juni 2016 bertempat di laboratorium Kesehatan Kendari. Sampel dalam penelitian ini adalah ekstrak daun tumbuhan C. trifolia L. Domin.

Alat-alat yang digunakan dalam penelitian; Autoklaf, cawan petri, cylinder cup, erlenmeyer dan tabung reaksi, gelas ukur, inkubator, jarum ose, minibiotik/jangka sorong, labu tentukur, laminar air flow, lampu spiritus, oven, pipet mikro, pinset, timbangan gram dan timbangan analitik, mikser dan tube mikser.

Bahan-bahan yang digunakan dalam penelitian; Daun C. trifolia L. Domin, 
bakteri E. coli, media antibiotic medium 1, etanol 96\%, akuades dan amoxicilin.

Pembuatan ekstrak etanol daun Cayratia trifolia L. Domin.

Ditimbang bahan sebanyak 300 gram, Dimasukan dalam wadah maserasi, Ditambahkan etanol 96\% sebanyak 2250 $\mathrm{mL}$ ditutup dengan aluminium foil dibalut dengan lakban tutup rapat, disimpan selama 3 hari pada suhu kamar dan terlindung dari cahaya sambil diaduk sehari sekali, setelah 3 hari disaring menggunakan kain flanel kemudian hasil penyaringannya disimpan di dalam botol atau wadah dan diberi etiket (Harborne, 1987).

\section{Pengujian Aktivitas Antibakteri Ekstrak daun Cayratia trifolia L.Domin.}

Tuang media AB 1 (antibiotik medium 1) sebanyak $15 \mathrm{~mL}$ dalam cawan petri untuk lapisan pertama dan biarkan memadat. Bakteri yang telah disuspensikan dalam $\mathrm{NaCl} \quad 0.9 \%$ dipipet sebanyak $1 \mathrm{~mL}$ lalu dimasukan ke dalam erlenmeyer yang berisi $100 \mathrm{~mL}$ medium antibiotik, dikocok hingga homogen dan dipipet $5 \mathrm{~mL}$ ke cawan petri untuk lapisan kedua. Letakan cylinder cup pada permukaan agar yang telah memadat. dimasukan ekstrak etanol $C$. trifolia L. Domin, ke dalam lubang cylinder cup dengan cara meneteskan sampai penuh, kontrol positif (Amoxicilin) dan kontrol negatif (Akuades) dibiarkan pada suhu kamar \pm 15 menit lalu diinkubasi $37^{\circ} \mathrm{C}$ selama 24 jam, lalu dikeluarkan dari inkubator. Kemudian diamati luas daerah hambatan bakteri menggunakan jangka sorong (Pratama, 2005).

\section{HASIL PENELITIAN}

Hasil pengujian aktivitas antibakteri ekstrak etanol daun $C$. trifolia L. Domin terhadap bakteri E. coli dapat dilihat pada Tabel 1 dan Gambar 1 berikut ini : 
Tabel 1. Hasil pengukuran zona hambat ekstrak etanol daun C. trifolia L. Domin terhadap bakteri $E$. coli.

\begin{tabular}{|c|c|c|c|c|c|}
\hline \multirow[b]{2}{*}{ Perlakuan } & \multicolumn{3}{|c|}{ Diameter Zona Hambat (mm) } & \multirow[b]{2}{*}{$\begin{array}{l}\text { Total } \\
(\mathrm{mm})\end{array}$} & \multirow[b]{2}{*}{$\begin{array}{l}\text { Rata-rata } \\
\text { (mm) }\end{array}$} \\
\hline & \multicolumn{3}{|c|}{ Pengulangan } & & \\
\hline & $\mathrm{I}$ & II & III & & \\
\hline Ekstrak 10\% & 9 & 8 & 6 & 23 & 7,67 \\
\hline Ekstrak 20\% & 12 & 10 & 9 & 31 & 10,33 \\
\hline Ekstrak 30\% & 16 & 12 & 14 & 42 & 14,00 \\
\hline Kotrol $+(\mathrm{K}+)$ & 18 & 16 & 15 & 49 & 16,33 \\
\hline Kontrol - (K-) & 0 & 0 & 0 & 0 & 0 \\
\hline
\end{tabular}

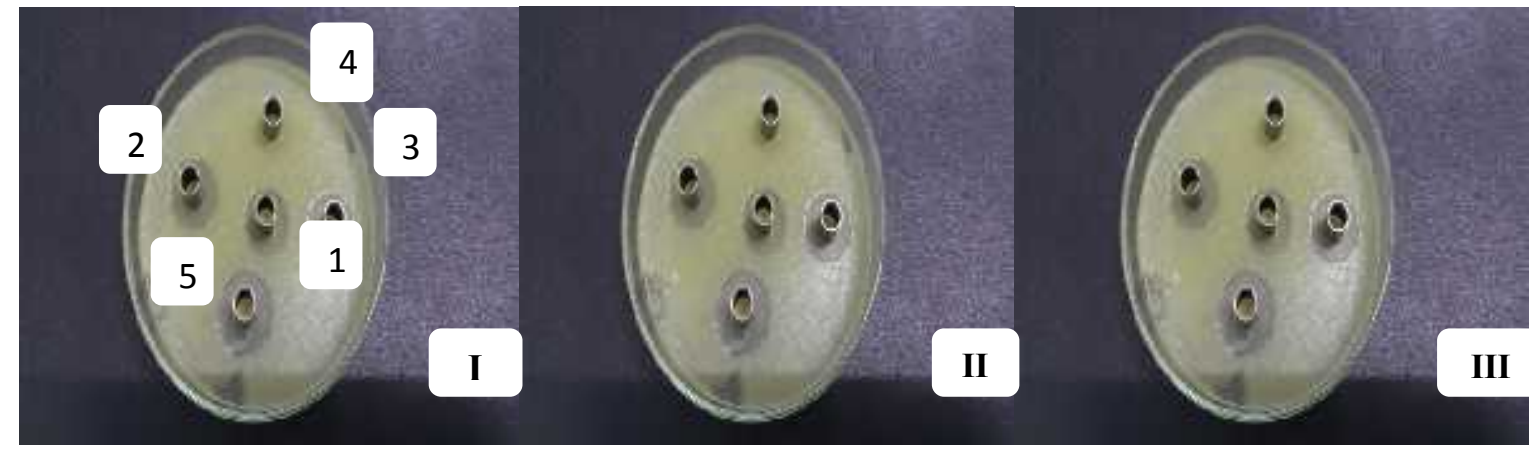

Gambar 1. Hasil pengijian aktivitas antibakteri ekstrak etanol daun C. trifolia L. Domin terhadap pertumbihan bakteri E. coli (I, II, III = ulangan, 1: konsentrasi 10\%, 2: $20 \%, 3: 30 \%, 4:$ kontrol positif, 5: kontrol negatif)

\section{PEMBAHASAN}

Pada Tabel 1 dapat dilihat bahwa rata-rata zona hambat dari perlakuan ekstrak, kontrol positif dan kontrol negatif memiliki perbedaan, untuk ekstrak konsentrasi $10 \%$ memiliki rata-rata zona hambat 7,67 mm, konsentrasi $20 \%$ ratarata zona hambat $10,33 \mathrm{~mm}$, konsentrasi $30 \%$ rata-rata zona hambat $14,00 \mathrm{~mm}$, sedangkan untuk kontrol positif (Amoxicillin) memiliki rata-rata zona hambat 16,33 mm, dan akuades (kontrol negatif) tidak memiliki zona hambat. Dari hasil zona hambat pertumbuhan bakteri dipengaruhi oleh kepekatan konsentrasi ekstrak etanol daun C. trifolia L. Domin. Besar zona hambatannya terhadap pertumbuhan bakteri E. coli, sampai ada batas tertinggi (kosentrasi 30\%) dari ketiga kosentrasi yang digunakan, daun $C$. trifolia L. Domin yang mengandung senyawa flavonoid (Ilyas dkk., 2016), dimana flavanoid dapat bersifat antibakteri karena adanya gugus fenol yang bersifat sebagai koagulator protein yang dapat mengganggu sintesis membran sel serta proses metabolism yang menggunakan protein tidak akan terjadi (Dwidjosaputro, 2010). Mekanisme lain flavanoid sebagai 
antibakteri yaitu diduga menghambat asam nukleat dalam cincin A dan B yang memegang peran penting dalam proses interkelasi atau ikatan hidrogen dengan menumpuk basa asam nukleat yang menghambat pembentukan DNA dan RNA sel mikroba (Cushnie \& Lamb, 2005), dan kemungkinan lain adalah flavonoid berperan secara langsung dengan mengganggu fungsi sel mikroorganisme dan penghambatan siklus sel mikroba. (Grubben, 2004, Pratiwi, 2014).

Pada Tabel 1 dilihat terdapat perbedaan rata-rata antara pengulangan I, II dan III pada kosentrasi 10\% memiliki rata-rata terendah dan $30 \%$ memiliki ratarata yang tinggi, bahwa ekstrak etanol daun C. trifolia L. Domin mempunyai daya hambat tertinggi terhadap pertumbuhan bakteri E. coli pada kosentrasi 30\%. Hal ini dapat dilihat dari $\mathrm{F}$ hitung yang lebih besar $(54,92)$ di bandingkan dengan $F$ tabel $(4,07)$. Dari data yang diperoleh kemudian dilanjutkan dengan uji statistik anova dimana diperoleh $\mathrm{F}$ hitung $(54,92) \mathrm{F}$ tabel $(4,07)$, dengan tingkat kepercayaan $95 \%$ (á=0,05). Dengan demikian ekstrak etanol daun $C$. trifolia L. Domin memiliki aktivitas antibakteri yang signifikan terhadap pertumbuhan bakteri E. coli.

\section{SIMPULAN}

Ekstrak etanol daun Cayratia trifolia L. Domin memiliki aktivitas antibakteri terhadap pertumbuhan bakteri E. coli dan pada konsentrasi $30 \%$ dari ekstrak etanol daun C. trifolia L.Domin efektif dalam menghambat pertumbuhan bakteri E. coli.

\section{SARAN}

Perlu dilakukan penelitian lebih lanjut untuk melakukan fraksinasi dari ekstrak etanol daun Galing ( $C$. trifolia L.Domin.) yang memiliki efak antibakteri terhadap bakteri E. coli. Perlu dilakukan penelitian lebih lanjut mengenai daya antibakteri jenis bakteri lain dan anti jamur dari ekstrak etanol daun $C$. trifolia $\mathrm{L}$. Domin.

\section{DAFTAR PUSTAKA}

BPOM. 2008. Informatorium Obat Nasional Indonesia, Badan Pengawas Obat dan Makanan Republik Indonesia: Jakarta.

Cushnie, T.P., dan Lamb A. J. 2005. Antimicrobial Activity of Flavanoids. Interantional Journal of Antimicrobial Agets. 26: 343356.

Dinas Kesehatan Kota Kendari. 2013. Profil Dinas Kesehatan Kota Kendari. Dinas Kesehatan Kota Kendari: Kendari.

Dwijoseputro. 2010. Dasar-Dasar Mikrobiologi. Djambatan: Jakarta.

Enggram, B. 1998. Rencana Asuhan Keperawatan Medikal Bedah. EGC: Jakarta.

Grubben, G. J. H. 2004. Plant Resources of Tropikal Afrika 2 : vegetables. Backhuys Publisher: Netherlands.

Harborne, J,B. 1987. Metode Fitokimia. ITB: Bandung. 
Ilyas, Y. Muhammad, Andi Mona, F.S., Karmilah. 2016. Efak Antidiabetes Ekstrak Etanol Daun Galing (Cayratia trifolia L.Domin.) Pada Mencit Jantan (Mus musculus) Yang Diinduksi Streptozotocin, Warta Farmasi. Prodi DIII Farmasi. Akademi Farmasi Bina Husada Kendari. 5 (1): 135-142.

Jawetz, E., dan Adelberg, E.A. 2001. Mikrobiologi Kedokteran Untuk Profesi Kedokteran. Jakarta.

Katzung, B,G. 2004. Farmakologi Dasar dan Klinik edisi 4. EGC: Jakarta. Hal. 709-719.

Kemenkes RI. 2014. Riset Kesehatan Daerah 2013: Jakarta.

Kumar, D., Gupta, J., Kumar, S., Arya, R.,Kumar, T. and Gupta, A. 2012. Pharmacognostic Evaluation of Cayratia trifolia (Linn.) Leaf. Asian Pacific journal of Tropical Biomedicine. 2:6-10.

Muhlisah, F. 2005. Tanaman Obat Nasional Indonesia. Badan Pengawas Obat dan Makanan Republik Indonesia: Jakarta.

Pratama, M. R. 2005. Pengaruh Ekstrak Serbuk Kayu Siwak (Salvadorapersica) Terhadap Pertumbuhan Bakteri Streptococcus mutans dan Staphylococcus aureus Dengan
Metode Difusi Agar. Skripsi. IPB. Bogor.

Pratiwi, S. T. 2014. Mikrobiologi farmasi. Jakarta: Erlangga.

Raina. 2011. Ensiklopedia Tanaman Obat Untuk Kesehatan. Absolut: Yogyakarta.

Saepudin. 2006. Pelayanan Kesehatan Maternal dan Neonatal. Yayasan Bina Pustaka: Jakarta.

Utami, N.S. 2014. Cayratia trifolia, Liar Memanjat Kaya Manfaat. Jakarta. https://biologinunik.com//cayratialiar-memanjat-kaya-manfaat, diakses 12 Maret 2016.

Widoyono. 2005. Penyakit Tropis: Epidemiologi, Penularan, Pencegahan dan Pemberantasannya. Erlangga Medical Series (EMS). Semarang.

Wijayakusuma, H. 1997. Tanaman berkhasiat obat Indonesia. Pustaka Kartini: Jakarta. 